\title{
Retrospective analyses of high-energy explosive device- related injuries of the ear and auricular region: experiences in an operative field hospital emergency room
}

\author{
Mehmet Burak Aşık, M.D., (1) Murat Binar, M.D.
}

Department of Otolaryngology and Head\&Neck Surgery, Gülhane Training and Research Hospital, Ankara-Turkey

\begin{abstract}
BACKGROUND: With the changing conditions of terrorism, particularly in urban areas, high-energy explosive devices such as improvised explosive devices (IEDs) and projectile missiles (PMs) are frequently used. Traumas caused by these devices particularly affect the maxillofacial region and typically lead to otologic problems. In this study, we aimed to evaluate otologic complaints, otoscopic and auricular examinations, and tuning-fork tests of patients who were exposed to high-energy blast-related injuries and perform a comparison between trauma patients injured by IEDs and PMs.
\end{abstract}

METHODS: The medical data of patients admitted to an operational field hospital emergency room with injuries related to highenergy explosive devices such as IEDs and PMs between July 27, 2015 and July 22, 2016 was reviewed. The hearing impairment, tinnitus, otologic examination, auricular region examination, and tuning-fork tests of all patients were evaluated. The otologic evaluation records of the patients $(n=86)$ were evaluated using a scoring system established by the authors. The patients were categorized into two groups according to the device causing the injury: IEDs in group I and PMs in group II.

RESULTS: A total of $24 \mathrm{I}$ combatants were injured by high-energy explosive devices. All patients were male with a mean age of 30.2 years (range, 20-54). Of these, 86 had hearing impairments that were detected by tuning-fork tests. Of those, 50 were injured by IEDs and 36 by PMs. Of the 86 patients, 18 had traumatic tympanic membrane perforation, and of those, 6 patients were injured by IEDs and 12 by PMs. Further, 68 of the 86 patients had sensorineural hearing loss, and of those, 44 were injured by IEDs and 24 by PMs. There was a statistically significant difference between the IED and PM groups according to otologic evaluation score $(P=0.044)$.

CONCLUSION: This study demonstrates that PMs can have a large impact on the human ear and may cause more severe otologic manifestations among combatants than those caused by IEDs. The early and accurate evaluation of patients exposed to high-energy explosive devices in an operational field is important for the appropriate management of these patients.

Keywords: Ear; high-energy explosive devices; otology; trauma; tuning-fork tests.

\section{INTRODUCTION}

With the changing nature of asymmetrical warfare, high-energy explosive device traumas are increasingly being seen. ${ }^{[1]}$ High-energy explosive devices such as improvised explosive devices (IEDs) and projectile missiles (PMs) are commonly employed by terrorist groups in urban areas, particularly at close range..$^{[1,2]}$ An IED is a "homemade" bomb and destructive device that is used to destroy and distract; therefore,
IEDs are occasionally used by terrorists and suicide bombers. A PM is a self-propelled rocket that is fired from a weapon and cannot be adjusted after launch. Both devices particularly cause maxillofacial region traumas and can lead to ear problems because of their high acoustic energy. Therefore, combatants exposed to close range explosives may have otologic problems as well as other systemic morbidities. Most of the injuries observed after high-explosive detonations comprise conventional blunt, penetrating, and thermal trauma. ${ }^{[2]}$

Cite this article as: Aşık MB, Binar M. Retrospective analyses of high-energy explosive device-related injuries of the ear and auricular region: experiences in an operative field hospital emergency room. Ulus Travma Acil Cerrahi Derg 2018;24:450-455.

Address for correspondence: Mehmet Burak Aşık, M.D.

Gülhane Eğitim ve Araştırma Hastanesi, KBB ve Baş-Boyun Cerrahisi Kliniği, Keçiören, 06018 Ankara, Turkey

Tel: +90 312 - 3045710 E-mail: burock312@yahoo.com

Ulus Travma Acil Cerrahi Derg 2018;24(5):450-455 DOI: 10.5505/tjtes.2017.60649 Submitted: 19.06.2017 Accepted: II.12.2017 Online: 10.09.2018

Copyright 2018 Turkish Association of Trauma and Emergency Surgery 
Depending on the duration and strength of the sound pressure affecting the human ear, isolated or combined otologic manifestations, such as ear drum perforation, interruption of the middle ear ossicle chain, and inner ear damage, may occur. ${ }^{[3,4]}$ Otoscopy, pure tone audiometry, measurement of otoacoustic emissions, radiological assessment, and neurotologic evaluation are used to determine the severity of the trauma. With prompt and adequate therapy, permanent hearing loss can be minimized. ${ }^{[2,3]}$ However, many combat areas are far away from tertiary hospitals, and nowadays, health care is provided by operational field hospitals in most countries. Although the transportation of patients can be easily arranged, the first doctor in charge at an operational field hospital is responsible for the evaluation and management of the patients.

The early and accurate assessment of injured patients in an operational field hospital is a vital part of the care for patients with otologic trauma. Audiological assessment is critical in the evaluation of acoustic trauma patients, but there may not be an audiological unit in operation field hospitals. Therefore, only two methods exist for the evaluation of such patients in these hospitals: otologic examination and tuning-fork tests.

In this study, we aimed to evaluate otologic complaints, otoscopic and auricular examinations, and tuning-fork tests of combatants who were exposed to high-energy blast-related injuries in the operational field. We also aimed to share our experience that was gained in the operational field hospital. We performed a comparison between trauma patients injured by IEDs and PMs based on otologic assessment.

\section{MATERIALS AND METHODS}

\section{Patient Selection}

Review board approval was obtained for this retrospective study (KAEK-I5-II03/13.04.2016). Patients who had been admitted to an operational field emergency room because of exposure to and injury by high-energy explosive devices between July 2015 and July 2016 were retrospectively enrolled. Patients were excluded if they had more severe systemic morbidities other than ear problems or had undergone emergency surgical intervention because of other fatal reasons. Based on their exposure to different explosive devices, the study population was divided into two subgroups: the IED group and the PM group. All patients were asked if they had any otologic complaints such as hearing loss and tinnitus. Additionally, they were asked if they had further complaints such as vertigo. However, none of them had vertigo.

\section{Tuning Fork Tests}

After otoscopic examination and temporal region evaluation, tuning-fork tests (Weber and Rinne tests) were performed in the frequency range of 256-5 $12 \mathrm{~Hz}$ (We had only two kinds of tuning-fork instruments in the operational field hospital, which were at 256 and $5 / 2 \mathrm{~Hz}$ ). All the tuning tests were performed by the author (M.B.A.) who was an otolaryngologist and head-neck surgeon in an operational field hospital. The Weber test was used to detect unilateral conductive and unilateral sensorineural hearing loss. A vibrating fork was placed over the forehead/vertex/chin of the patient, and the patient was instructed to indicate the ear in which sound could be better heard. In normal ear and in bilateral equally hearing loss, the sound would be heard at the midline. A patient with a unilateral (one-sided) conductive hearing loss would hear the tuning fork loudest in the affected ear. This is because the conduction problem masks the ambient noise of the environment, while the wellfunctioning inner ear detects the sound via the bones of the skull, causing it to be perceived as a louder sound than in the unaffected ear. In unilateral sensorineural hearing loss or unilateral total hearing loss, the sound would be heard best in the unaffected ear. Therefore, this test is very useful in patients with hearing that is different between the two ears. It cannot confirm normal hearing because it does not measure sound sensitivity in a quantitative manner. Hearing defects affecting both ears equally, e.g., bilateral equally hearing loss, would produce an apparently normal test result. Following the Weber test, the Rinne test was applied. The Rinne test is used to compare air conduction with bone conduction thresholds. Under normal circumstances, air conduction is better than bone conduction. The tuning fork should be struck against the elbow or knee of the patient to vibrate. While striking, care must be taken that the strike is made at the junction of the upper 1/3 and lower 2/3 of the fork. This is the maximum vibratory area of the tuning fork. It should not be struck against a metallic object because it can cause overtones. As soon as the fork begins to vibrate, it is placed at the mastoid process of the patient. The patient is advised to signal when he (she) stops hearing the sound. As soon as the patient signals that he is unable to hear the sound anymore, the vibrating fork is immediately transferred close to the external auditory canal. In patients with normal hearing, he (she) should be able to hear the fork as soon as it is transferred to the front of the ear. This result is known as positive Rinne test (air conduction is better than bone conduction). In case of conductive hearing loss, the patient will not be able to hear the fork sufficiently as soon as it is transferred to the front of the ear (bone conduction is better than air conduction). This is known as negative Rinne test. If the patient is suffering from profound or total unilateral hearing loss (i.e., a "dead" ear), the sound would still be heard through the bone conduction of opposite ear, but will not be heard when the tuning fork is transferred to the external auditory canal of affected ear. This condition leads to a false negative Rinne. If sensorineural hearing loss exists, both bone and air conduction time decreases, so the ratio of air/bone conduction time remains the same. This is called pathological positive Rinne. Tuning-fork test results are summarized in Table I. Based on these tests, the type of hearing loss was determined. 
Table I. Explanations of tuning-fork tests

\begin{tabular}{|c|c|c|c|c|}
\hline Test & Normal hearing & Conductive hearing loss & Sensorineural hearing loss & Total hearing loss \\
\hline Rinne & $\begin{array}{c}\text { AC time }>\text { BC time } \\
\text { (positive Rinne) }\end{array}$ & $\begin{array}{c}\text { AC time }<\text { BC time } \\
\text { (negative Rinne) }\end{array}$ & $\begin{array}{c}\text { AC time }>\text { BC time; } \\
\text { but both decrease } \\
\text { (pathological positive Rinne) }\end{array}$ & $\begin{array}{c}\mathrm{BC}+\text { (heard from opposite ear) } \\
\mathrm{AC} \text { - (sound cannot be heard) } \\
\text { (false negative Rinne) }\end{array}$ \\
\hline Weber & $\begin{array}{l}\text { Sound is heard } \\
\text { at midline }\end{array}$ & $\begin{array}{l}\text { Sound is heard better } \\
\text { in bad ear }\end{array}$ & $\begin{array}{l}\text { Sound is heard better } \\
\text { in good ear }\end{array}$ & Sound is heard in good ear \\
\hline
\end{tabular}

\section{Otologic Examination and Scoring System}

According to the otoscopic examinations and tuning-fork tests, the severity of the otologic situation of the patients was assessed via a scoring system described as follows: complaint of hearing loss (I point), complaint of tinnitus (I point), conductive or sensorineural hearing loss detected by tuning-fork tests (I point), tympanic membrane perforation (I point), and auricula defect ( $\mathrm{I}$ point). As a result of this scoring system, a patient could be given a maximum of 5 points. $A$ comparison was made between the IED and the PM groups. After the appropriate first treatment application, the patients were referred to a tertiary center for audiological tests, radiologic assessment, and possible medical/surgical treatment, due to lack of an audiological unit in the operation field hospital. A patient exposed to IED trauma is shown in Figure I.

\section{Statistical Analysis}

Statistical analyses were performed using SPSS for Win. Ver.I5.0 (SPSS Inc., Chicago, IL., USA). After the variables were investigated to determine whether they were normally distributed, the Mann-Whitney $U$ test was used for the comparison of continuous variables between two groups. Significance was defined as $\mathrm{p}<0.05$.

\section{RESULTS}

A total of 281 combatants were injured by high-energy explosive devices. All patients were male, with a mean age of 30.2 years (range, 20-54). Of those, 40 combatants could not be

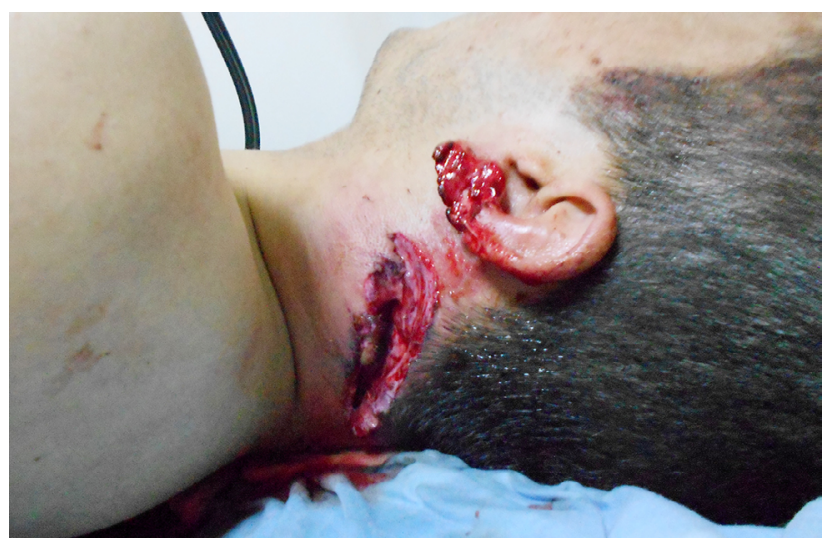

Figure 1. Auricular defect due to IED trauma.
Table 2. The complaints and examination findings in the groups

\begin{tabular}{lccc}
\hline & IED $(\mathbf{n = 5 0 )}$ & & PM $(\mathbf{n = 3 6 )}$ \\
\cline { 2 - 2 } & $\mathbf{n}(\%)$ & & $\mathbf{n}(\%)$ \\
\hline Complaints of hearing loss & $50(100)$ & & $36(100)$ \\
Complaints of tinnitus & $42(84)$ & & $30(83)$ \\
Hearing loss (tuning-fork tests) & $50(100)$ & & $36(100)$ \\
Tympanic membrane perforation & $6(12)$ & & $12(33)$ \\
Auricula defects & $2(4)$ & & $10(28)$ \\
\hline
\end{tabular}

IED: Improvised explosive device; PM: Projectile missile.

examined owing to their critical vital and clinical conditions in the emergency room. Of the remaining 241 patients with otologic complaints, I 33 were IED-injured combatants and 108 were PM-injured combatants. Of 24I, 86 had both hearing impairment complaint and otologic findings. Of those, 50 were injured by IEDs and 36 were injured by PMs. The flowchart showing the management of the patients is shown in Figure 2.

After brief anamnesis and recording hearing impairment and tinnitus complaints, all patients underwent otoscopic examination. Eighteen patients had traumatic tympanic membrane perforation, and of those, 6 patients were injured by IEDs and 12 by PMs. Twelve patients had auricular defects, and of those, 2 patients were injured by IEDs and 10 by PMs. All the patients with auricula defects were injured partially and none of them had external auditory canal defect. In all patients with traumatic tympanic membrane perforation $(n=18)$, conductive hearing loss was also detected by tuning-fork tests. Of those, 6 patients were injured by IEDs and 12 by PMs. Sixtyeight out of 86 had sensorineural hearing loss that was detected by tuning-fork tests. Of those, 44 had IED injury and 24 had PM injury (Table 2).

The mean IED $(n=50)$ otologic evaluation score was $3 \pm 0.69$, and the median was 3 . The mean PM $(n=36)$ otologic evaluation score was $3.44 \pm 1.02$, and the median was 3 . There was a statistically significant difference between the IED and PM groups based on the otologic evaluation score $(p=0.044)$. 


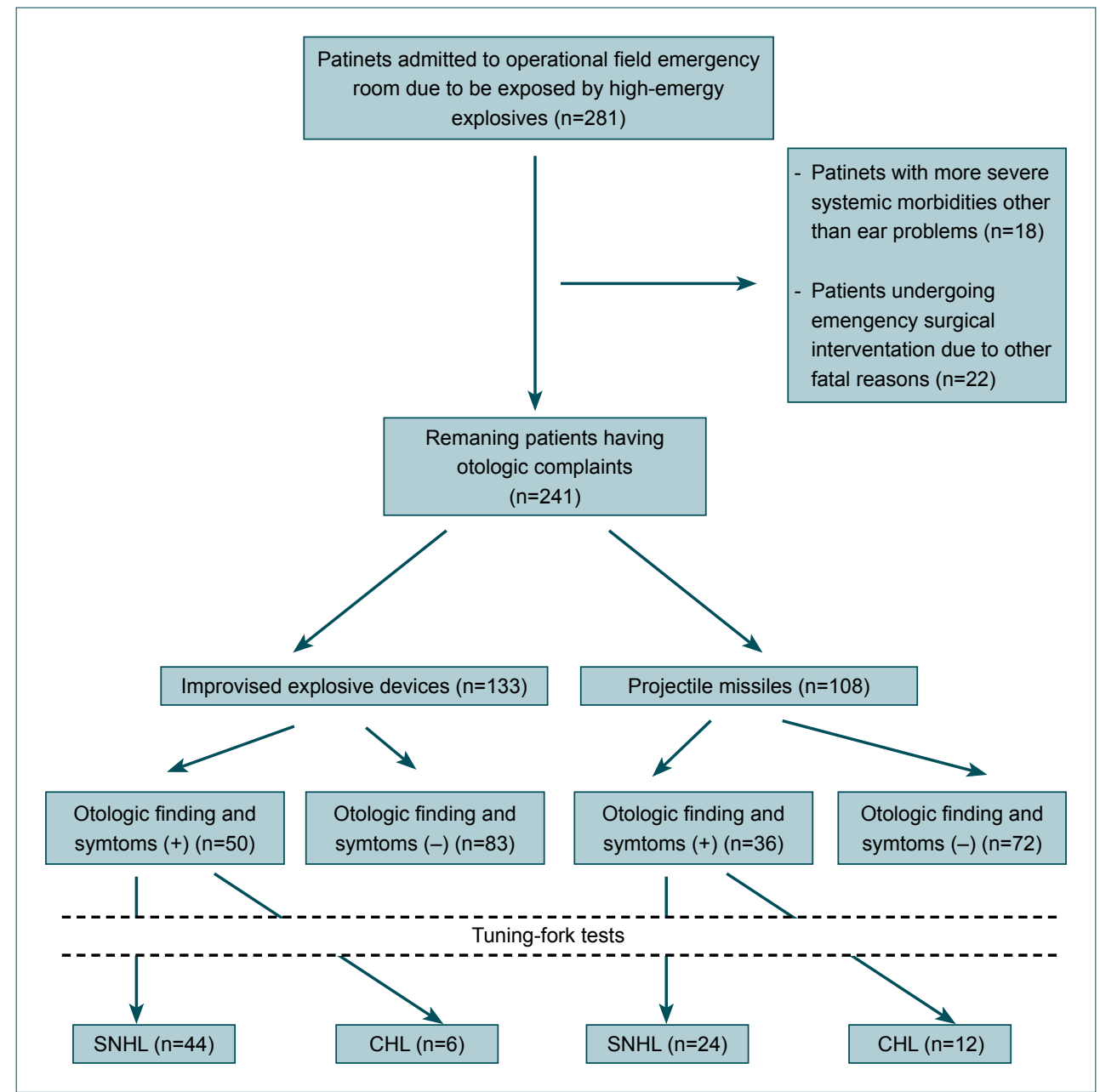

Figure 2. Flowchart of enrolled patients according to otologic examination and tuning-fork tests. SNHL: Sensorineural hearing loss; CHL: Conductive hearing loss.

The findings of tympanic membrane perforation and auricula defect were more common in the PM than in the IED group (Table 2).

\section{DISCUSSION}

Given the outcomes of this study, high-energy explosive devices such as IEDs and PMs can cause various degrees of otologic injuries among combatants. Moreover, otologic trauma caused by PMs appears to be more severe compared with that caused by IEDs. Although both PMs and IEDs are categorized as high-energy explosives, their use in urban terrorist attacks varies from each other. IED detonations occur frequently when combatants are deployed in a military vehicle or behind a defilade position. ${ }^{[5]}$ Moreover, these two high-energy explosives are frequently used in urban areas by terrorist groups. ${ }^{[5,6]}$

IEDs that are trapped on the roadside or in a wall are detonated while combatants are walking or entering a building, or while their vehicles are crossing. Therefore, a combatant is exposed to a blast behind a protected area or in an armored vehicle. ${ }^{[7]}$ Most of the time, mortal injuries occur when a combatant is exposed directly to the detonation. ${ }^{[5,8]}$ PMs are frequently used in two different ways; toward the area where combatants typically exist or directly to combatants during planned terrorist attacks. Therefore, there may be more detonation effects on combatants and their surroundings. Although PMs create lower detonation energies than IEDs, the detonation of a PM directly affects the combatant. ${ }^{[8,9]}$ As expected from the given information, the statistical analysis also revealed that more otologic morbidity was observed by PM detonation among the combatants.

According to outcomes of this study, the number of patients experiencing sensorineural hearing loss due to the effect of acoustic trauma after detonation was higher than those experiencing conductive hearing loss. Hearing impairment and tinnitus complaints due to IED injuries were observed much more compared with PMs. However, in injuries caused by PMs, there were more findings in the otoscopic and auricular examinations. Although it was not confirmed statistically, we also observed that tympanic membrane perforations and auricular defects occurred more frequently in combatants injured by PM explosions. 
Emergency service assessment is always the most critical step in the evaluation of trauma patients, and morbidity is significantly reduced in these patients, who are evaluated correctly without wasting time. ${ }^{[5,9]}$ In the literature search, we found several studies that evaluated trauma patients exposed to blastic traumas using audiological assessment. ${ }^{[3,10,11]}$ Because of the absence of audiological units in the operation field hospital, we were unable to evaluate the patients with pure tone audiogram. Therefore, we were able to investigate the pre-diagnosis of patients with or without the findings of otoscopic examination and tuning-fork tests. Transportation to tertiary hospitals was promptly performed to provide appropriate treatment and audiological assessment for these patients. The use of tuning-fork tests as a first-step instrument for detection of hearing levels is fairly limited nowadays owing to the easy accessibility of audiometry in hospitals; however, we recommend their routine use in cases where physicians have no access to audiological units and quick evaluation for triage is required.

The limitations of this study included the lack of ability to confirm the findings with the radiological and audiological records of the trauma patients. The data analyzed for this study showed that a few primary records of the patients were insufficient for forensic and medical evaluations. Moreover, there was a lack of data on the post-injury complications and comprehensive treatment of these patients.

The results of this study are important for operational field doctors as well as combatants and their commanders. The doctors are responsible for diagnosis and appropriate treatment. Owing to the lack of audiological units and otologic equipment in most of these hospitals, doctors and commanders should take precautions for early transportation of injured patients. Although ballistic shielding for ears is considered sufficient for combatants to avoid otologic morbidity, its utility in operational fields should be discussed. Further studies and investigations on the protection of ears in combat areas should be performed by ballistic experts and otolaryngologists.

\section{Conclusion}

This study demonstrated that PMs can have a larger impact on the human ear and may cause more severe otologic manifes- tations among combatants than IEDs. The early and accurate evaluation and appropriate treatment of patients exposed to otologic injury in an operational field should be of utmost importance. Otolaryngologists working in operational field hospitals should use all possible instruments to reach an early diagnosis regarding the otologic condition and provide the transportation of these patients as early as possible.

Conflict of interest: None declared.

\section{REFERENCES}

1. Martí M, Parrón M, Baudraxler F, Royo A, Gómez León N, Alvarez-Sala R. Blast injuries from Madrid terrorist bombing attacks on March 11, 2004. Emerg Radiol 2006;13:113-22. [CrossRef]

2. Aşık MB, Akay S, Eksert S. Analyses of combat-related injuries to the maxillofacial and cervical regions and experiences in an operational field hospital. Ulus Travma Acil Cerrahi Derg 2018;24:56-60.

3. Wightman JM, Gladish SL. Explosions and Blast Injuries. Ann Emerg Med 2001;37:664-78. [CrossRef]

4. Mrena R, Pääkkönen R, Bäck L, Pirvola U, Ylikoski J. Otologic consequences of blast exposure: a Finnish case study of a shopping mall bomb explosion. Acta Otolaryngol. 2004;124:946-52. [CrossRef]

5. Garth RJN. Blast injury of the ear. In: Cooper GJ, Dudley HAF, Gann DS, Little RA, Marynard RL, editors. Scientific Foundations of Trauma. Oxford: Butterworth-Heinemann; 1997. p. 225-35.

6. Salinas NL, Brennan J, Gibbons MD. Massive facial trauma following improvised explosive device blasts in Operation Iraqi Freedom. Otolaryngol Head Neck Surg 2011;144:703-7. [CrossRef]

7. Peleg K, Aharonson-Daniel L, Michael M, Shapira SC; Israel Trauma Group. Patterns of injury in hospitalized terrorist victims. Am J Emerg Med 2003;21:258-62. [CrossRef]

8. Ramasamy A, Masouros SD, Newell N, Hill AM, Proud WG, Brown $\mathrm{KA}$, et al. In-vehicle extremity injuries from improvised explosive devices: current and future foci. Philos Trans R Soc Lond B Biol Sci 2011;366:160-70. [CrossRef]

9. Brennan J. Head and neck trauma in Iraq and Afghanistan: different war, different surgery, lessons learned. Laryngoscope 2013;123:2411-7.

10. Wordsworth M, Thomas R, Breeze J, Evriviades D, Baden J, Hettiaratchy $\mathrm{S}$. The surgical management of facial trauma in British soldiers during combat operations in Afghanistan. Injury 2017;48:70-4. [CrossRef]

11. Ballivet de Régloix S, Crambert A, Maurin O, Lisan Q, Marty S, Pons Y. Blast injury of the ear by massive explosion: a review of 41 cases. J R Army Med Corps 2017;163:333-8. [CrossRef] 


\section{ORİJINAL ÇALIŞMA - ÖZET}

\section{Kulak ve aurikular bölgenin yüksek enerjili patlayıcılar kaynaklı yaralanmalarının geriye dönük analizi: Operasyon saha hastanesi acil servis deneyimleri \\ Dr. Mehmet Burak Aşık, Dr. Murat Binar}

Gülhane Eğitim ve Araştırma Hastanesi, Kulak Burun Boğaz ve Baş-Boyun Cerrahisi Kliniği, Ankara

AMAÇ: Terörizmin koşulları değiştikçe, özellikle kentsel alanlarda, el yapımı patlayıcılar gibi yüksek enerjili patlayıcı maddeler sıklıkla kullanılmaktadır. Bu travmalar özellikle maksillofasiyal bölgeyi etkiler ve genellikle otolojik problemler yaratırlar. Bu çalışma, yüksek enerjili patlamayla ilişkili yaralanmalara maruz kalan hastaların otolojik şikayetlerini, otoskopik ve auriküler muayene ve diyapozon testlerini değerlendirmeyi ve otolojik değerlendirme skorlarına dayanarak el yapımı patlayıcılar (IED) ve rokete (PM) bağlı yaralanan travma hastaları arasında bir karşılaştırma yapmayı amaçlamıştır. GEREÇ VE YÖNTEM: 27 Temmuz 2015 ile 22 Temmuz 2016 tarihleri arasında el yapımı patlayıcı EYP ve roket PM nedeniyle yaralanan ve operasyonel saha hastanesi acil servisine başvuran 24 I hastanın tıbbi verileri gözden geçirildi. Tüm hastalar için işitme bozukluğu, kulak çınlaması şikayetleri, otolojik muayene, aurikuler bölgede muayene ve diyapozon testleri yapıldı ve otolojik problemi olan hastaların ( $n=86$ ) otolojik değerlendirme skoru kayıtları değerlendirildi. Hastalar yaralanmaya neden olan cihaza göre iki gruba ayrıldı: Grup l'de IED, grup Il'de PM'ler.

BULGULAR: İki yüz kırk bir savaşçı, yüksek enerjili patlayıcılarla yaralanmıştı. Tüm hastalar erkekti ve yaş ortalaması 30.2 idi (aralık 20-54). İki yüz kırk birinden 86'sında işitme şikayeti mevcuttu. Bunların 50'sinin IED tarafından yaralanması ve 36'sı PM tarafından yaralanmıştı. Seksen altı hastanın 18 'inde travmatik timpanik membran perforasyonu vardı ve altı hasta IED, 12 hasta PM nedeniyle yaralanmıştı. Seksen altı hastanın 68'inde sensorinöral işitme kaybı vardı ve bu hastaların 44'ünde IED yaralanması ve 24 'ünde PM yaralanması vardı. Otolojik değerlendirme skoruna göre IED ve PM grupları arasında istatistiksel olarak anlamlı farklılık vardı $(p=0.044)$.

TARTIŞMA: Bu çalışma, roket yaralanmalarının insan kulağında daha büyük bir etkiye neden olabileceğini ve travma hastaları arasında el yapımı patlayıcılara göre daha şiddetli otolojik bulgular yarattığını gösterdi. Operasyonel saha hastanesi gibi acil müdahale alanlarında otolojik yaralanmaya maruz kalan hastaların erken ve doğru değerlendirilmesi ve uygun tedavisi çok önemlidir.

Anahtar sözcükler: Diyapozon testleri; kulak; otoloji; travma; yüksek enerjili patlayıcılar.

Ulus Travma Acil Cerrahi Derg 20I8;24(5):450-455 doi: 10.5505/tjtes.2017.60649 